\title{
RELIGIOUS SELFCONCEPTIONS AMONG MUSLIM ADOLESCENTS IN HAMBURG, GERMANY
}

\author{
Ursula Günther \\ University of Hamburg \\ Germany
}

\begin{abstract}
This article considers five recent empirical studies dealing with religious selfconceptions among Muslim adolescents and assembles selected results. Embedded in the particular German migration context, these results emphasise that changes of paradigm within the discourses about Islam and Muslims have taken place since Huntington's scenario of the clash of civilisations. The fact that researchers are now attending to the societal reality of religious and cultural pluralism indicates that perspectives on religion and religiosity among Muslims have undergone considerable changes. The conclusion outlines briefly the challenges for religious education with regard to the contextual changes in migration and an increase in individual approaches to religion and religiosity.
\end{abstract}

Key Concepts: Muslim adolescents, societal reality, pluralism, perspectives, religiosity

\section{Introduction}

In the first half of the 1990s Mohammed Arkoun, a Muslim scholar and thinker who moved beyond both cultural and intellectual borders, had already predicted that the $21^{\text {st }}$ century would become the century of religion, a century of revisiting the impact and meaning of religion. He went further to state that the space of religions and their capability in coping with the challenges of intellectual modernity would be at stake. ${ }^{1}$ In a certain sense we are obliged to agree. At first glance one is inclined to predict this will become the century of Islam. But appearances are deceptive.

Globalisation and post-modernity which entail disenchantment with divine powers have left very few domains untouched. The effect can be summarised as follows: There is only one certainty you can rely on, namely that certainty no longer exists; we have to cope with a radical plurality of meaning.In such a context of uncertainty and insecurity the search for meaning and for answers in an environment often perceived as threatening, takes on new dimensions. This seems to be more obvious within societies undergoing social transformation of the kind currently taking place in Germany. Migration - to a great extent migration of Muslims - has transformed the relatively homogeneous German society into a multicultural and multi-religious one. By now the third generation of migrants have reached adolescence. Germany's Muslims count more than 3.000.000 and contribute to increasing societal, cultural and religious pluralism (Spuler-Stegemann, 2001:221; Bundesministerium des Inneren, 2000; Statisches Bundesamt Wiesbaden, 2000; Islamarchiv Bremen, 2000). ${ }^{2}$ Societal changes due to migration are widely evident. At school, for example, they find ex-

\footnotetext{
Verbatim from several conversations with Arkoun and from correspondence with him.

The details regarding religious affiliation are not representative; all sources refer to estimated values. Counting about 2000000 , the Muslims of Turkish origin form the majority. Naturalized foreigners are not repre-
} 
cietal changes due to migration are widely evident. At school, for example, they find expression in different class structures and class compositions. Cultural, linguistic and religious diversity is regular in most of the schools, at least in big cities and metropolitan areas. This necessitates different approaches to and concepts of teaching. Other social competences than before, are in demand for teachers as well as pupils. This includes capabilities in intercultural and inter-religious dialogue. Nevertheless a suitably adjusted conceptual framework is, for various reasons, still in its infancy.

Despite the fact that Germany is a multicultural society its Muslim population is often still perceived as being foreign or alien (Heitmeyer, 2003:13-32). ${ }^{3}$ The majority of Germans equate being Muslim with being religious, and Muslim religiosity with being very orthodox, even with tendencies to religious fundamentalism. Needless to say that Germans are in significant international company in keeping such images alive. The current public discourse concerning the debate whether veiled teachers in public schools might pose a threat and that therefore the veil should be forbidden legally, reflects growing awareness of the meaning of religion and religiosity. Since the (Christian) majority perceives itself as secular and enlightened the issue of religion and religiosity seems to refer only to Muslims. I emphasise the Christian, since I am convinced that the impact of Christianity on the selfconception of the majority is underestimated, also as part of the unconscious, in a certain sense the unthought of. However, the emotionality of the discourses reveals that there must be some projections at work, reflecting uncertainties of the majority (Rommelspacher, 2002). ${ }^{4}$ More directly, I would say the presence of other, i.e. non-Christian, religious communities in Germany (mostly Muslims) that are perceived to be religious (as opposed to secular), confronts such a majority with its own shortcomings. There is a perceived threat in the pursuit of forms of religiosity apparently different to those familiar to the majority. It is evident that despite a social reality which has become established over a period of almost 50 years, inter-religious knowledge in general and such knowledge applied to the German context in particular, does not correspond to this reality. One of the reasons is probably the fact that Muslim migrants have been perceived as temporary visitors all along; a perception which coincides with the self-conception of the first generation of migrants. Therefore hardly anybody felt the necessity to seriously confront the other with its different cultural and religious background (Lutz, 1999). ${ }^{5}$ This has contributed to social interaction being very limited.

In what follows I shall take a closer look at selected recent empirical studies undertaken in the social sciences, religious studies and intercultural education dealing with (changing) religious self-conceptions among Muslim adolescents that, with a single exception, contra-

sented in the statistics, their numbers are estimated at 650000 . The same applies for German converts, whose numbers are estimated at about 120000 .

3 Heitmeyer points out that the societal landscape in Germany is characterized by the concept of group-specific misanthropy, like e.g. racism, sexism, antisemitism and islamophobia (ibid. 14-15). The latter is one of the major challenges for the German society.

4 Considering the discourse on wearing the veil in Germany, with a view to repercussions after the judgement of the constitutional court, this is excessively evident. Rommelspacher's analysis of the different discourses regarding the veil are very critical.

5 Lutz analyses the changes in the perception of Germany's immigrant workers and the expressions used to describe them. Foreign or immigrant workers (i.e. Gastarbeiter, a term that implies they are considered to be temporary visitors) have over an extended period been called foreigners - even if they had already been naturalised. This remains the same for the second and third generation, born and brought up in Germany. 
dict popular public discourses. ${ }^{6}$ First I shall outline the studies as such, second I shall assemble selected results and place them in the particular German migration context. Despite the heterogeneity of these studies in terms of methodology, theoretical framework and discipline the synopsis reveals interesting results that complement each another. In conclusion I shall mention some challenges for religious education, taking into consideration the fact that the creation of concepts adapted to the changing societal context, are on the agenda.

\section{Migration as a Field of Research in Reflecting on Muslims in Germany}

Migration as a field of research reflects national and international discourses with regard to Islam. It is beyond the scope of this article to go into such detail. The term image of the enemy (i.e. Feindbild) in the sense Islam as the new threat, especially after the fall of the Iron Curtain and the collapse of the communist system, and a whole range of attached associations will suffice to give the scope of such discussions. In the course of the mid-1980s the focus of scientific attention in the issue of migration shifted: Religion and religiosity, particularly Islam in the West, turned out to be interesting objects of research. Religion, i.e. Islam, has often served in explicating supposedly inadequate integration of migrants in western societies.

In the case of Germany one has to be precise on two different levels: First, research focussed predominantly on people of Turkish origin since they form the majority both of migrants and of Muslims in Germany, and second, research concentrated mainly on organised Muslims, often without mentioning either the denominational diversity of Islam or the spectrum of religiosity (like e.g. a secular, orthodox, traditional or individualised approach to religion). Such research has paid scant attention to those Muslims who characterise themselves as cultural Muslims and who, contrary to current assumptions and the media discourses, form the majority.

The discourses of the 1990s were shaped by Huntington's scenario of the clash of civilizations on the one hand and the counter-movement with a clear commitment to interreligious and intercultural dialogue on the other. These tendencies are reflected in research, specifically in respect of interpretations of social and religious phenomena. Both perspectives make clear that after considerable delay the societal reality of religious and cultural pluralism is now finally being tackled. In the course of the last five to seven years research perspectives on religion and religiosity among Muslims, especially in migration contexts, have again undergone considerable changes. Among the decisive factors are the influence of post-colonial theory and a new generation of researchers, partly with a bi-cultural background. Belonging to two (or even more) cultural systems, enables many to move beyond fixed cultural and/or intellectual boundaries and also allows them to build bridges and fill the space in between. The repercussions with regard to research have been and still are considerable. Eventually changes in religious self-conceptions or religiosity were related to the impact of migration on the one hand and the impact of discourses of the dominant culture on the other. There is a growing awareness that Germany is obliged to face the fact that it has become a multicultural and multi-religious society, even if this does not fit the selfconception of the (Christian) majority. At the same time Muslim adolescents have become the focus of attention. However, for the moment research has brought together only a small

6 The selection criterion here has been to focus on monographs because of their greater number of interviewees in comparison to articles, since the intention of this essay is a general overview in order to highlight tendencies and trends. This will form the basis of a larger research project. 
number of pieces of a supposedly large mosaic. Thus we do not yet have a satisfactory or comprehensive image of religiosity among adolescent Muslims in Germany. Also only limitedly available, are the necessary tools to develop educational approaches and concepts for taking up the abovementioned societal transformations.

\section{Research on Religiosity or Religious Self-conceptions of Muslim Adolescents in Germany/Hamburg: Introductory Remarks}

With the term religiosity I refer to an attitude and a behaviour concerning religion, religious institutions and theology. Therefore religiosity covers either descriptions from inside a religious denomination or community or descriptions from outside, sometimes even both at the same time (e.g. Mette/Rickers, 2001, the key word Religiosität).

During the last decade a shift has taken place in the self-perception of Muslims in Germany. The former migrant has become a citizen, with emphasis on loyalty to the constitution and a claim to civil rights equal to those of any other citizen. More precisely, Muslims currently demand to be considered as a religious community equal to Christian communities, with equal constitutional rights. This includes entitlement to state support with regard to religious education at school for Muslim pupils. The focus on Hamburg and Bremen, a city comparable to Hamburg regarding its Muslim population and an established culture of inter-religious dialogue, results from previously undertaken studies and the research project I am about to undertake. This deals with religiosity among Muslim adolescents in the triangle of community, school and family in a particular area of Hamburg. Although representative data on religiosity or religious self-conceptions of Muslim adolescents in Germany does not exist, the synopsis of available studies presented below, allows for an outline of tendencies. The results I shall present here do not correspond to the dominant public discourse shaped by the (Christian) majority and its perceptions of Islam and Muslim religiosity. Nevertheless, they indicate the need for questioning these discourses, shaped by the dominant culture. Further they invite, even compel, a paradigm shift within the German society that has to face its multicultural and multi-religious reality.

\section{Tempting Fundamentalism by Jürgen Heitmeyer et al}

I would like to start by referring to a quantitative study of 1997 aimed at analysing the impact of religion on young Turks of the third generation. Although the study was done at the exact time of the public discourse on Islam in Germany, it dramatised established, stereotyped perceptions and suspicions to such an extent that it contributed to worsening the controversy. This gave rise to further studies aimed at collecting more differentiated information and interpretations that were sensitive to the complexity of the issues. Thus the 1997 study marked a turning point in research on young Muslims in Germany. The title, Tempting Fundamentalism, reflects the results, or better said, the interpretation of the data and is revealing of the socio-political climate of the time in Germany. Almost all later studies depart from Tempting Fundamentalism, also in terms of methodological and theoretical approaches and transparency concerning the circumstances of collecting the data. Interestingly, such later studies achieve opposite results (Alacaçioğlu, 2000; Karaka oğlu-Aydın, 2000a; 2000b; Sandt, 1996; Tietze 2001). Heitmeyer and his research fellows came to the following conclusions: Fundamentalism is a widespread phenomenon among Turkish Muslim adolescents, they are prepared to use violence against unbelievers, they reject modernity and the Western way of life, and they claim the superiority of Islam (Heitmeyer/Müller/Schröder, 1997:32; 36). 
Notably the same research group recently published another study entitled German states according to which they detected growing islamophobia accompanied by racism and xenophobia (Heitmeyer, 2003).

\section{Religiosity among Muslim orientated Adolescents by Fred-Ole Sandt}

A study by Sandt in 1996 used qualitative methods of social science and focused on pupils' religiosity with a view to developing guidelines for religious education. The Muslim sample is only a part of the entire study and investigates Muslim religiosity in the context of migration (Sandt, 1996:233-255). The interviewees are found to be living within two cultural and religious contexts, which results in a departure from the religiosity of their parents and in a greater degree of diversity. Sandt identifies three types of attitudes toward religion among the youngsters, namely (i) critical questioning, (ii) acceptance of what is regarded as given, and (iii) interpretation (ibid.:248). Changes can be ascribed to firstly an orientation shaped by modern subjectivity and individualism, secondly daily life at school and within the community where they regularly cross borders, and thirdly experiences of exclusion and discrimination (ibid.:249-250). The mosque offers an experience of community, i.e. of believers. However, the majority of the interviewees do not go to the mosque. They locate their religious practice at home and within the family. These adolescents stress that the inner conviction according to the principles of Islam is more important than the formalised ritual. Orthodox adolescents react against secular processes of interpretation and reflection (ibid.:225-232).

\section{Muslim Adolescents in Turkish-Islamic Communities by Hasan Alacaçı lu}

This 1999 study uses an approach which combines quantitative and qualitative methods. Sponsored by the Muslim Council of Germany, the study aims, among other things, at disproving Heitmeyer et al. It also aims at giving insight into the ideological, political and religious positions of members of different Muslim umbrella bodies or associations, which are the only legal form of organisation for Muslims in Germany. ${ }^{7}$ Alacaçığlu stresses that the communities support the adolescents searching for identity. They frequent their traditional communities for the social, cultural and sport programmes offered rather than exclusively for religious reasons (Alacaçıŏlu, 1999:79). These leisure-time programmes are perceived as alternatives to public ones. Religious identity is regarded as a major component of identity; at the same time, the adolescents stress that Germany is their home country, since there are no legal restrictions concerning religious practises (ibid.:34-38). The author also mentions critical attitudes from within toward religious education by the communities: The methods of learning the Koran by heart are perceived to be old-fashioned and no longer adequate. Further they find community education does not provide enough basic knowledge of Islam (ibid.:94). Even adolescents, who consider themselves very religious, seem to be poorly equipped in such basic knowledge.

\footnotetext{
It is beyond the scope of this essay to explain the legal difficulties Muslim organisations face in Germany if they want official recognition. Muslims in Germany do not have any equivalent to the treaty between the state and the Catholic and Protestant churches (or the Council of Jews in Germany).For details see Rohe, 2001a; $2001 b$.
} 


\section{Islamic Identities - Forms of Muslim Religiosity among Adolescents in Germany and France by Nikola Tietze}

This comparative study of 2001 which uses qualitative methods of social science indicates that Muslim self-conceptions in Germany and France differ, because the relation statesociety-religion differs. Each country developed particular forms of religious organisations according to its traditions. These have an impact on the self-conceptions of Muslims. Islam in France is perceived from the angle of laicité, thus as an issue separate from state. In Germany, however, it is linked to the issue of integration (or non-integration) of the Turkish migrants (Tietze, 2001:7-18). Modernity and processes of individualisation have an impact on Muslim religiosity both in France and Germany. Tietze locates four dimensions shaping religious tradition. In each case special emphasis or priority is given to a different aspect of Muslim religiosity, namely a cultural, an ideological, an ethnical or a utopian aspect. Needless to say that there is much overlap between these aspects and that their relevance varies according to the context or situation (ibid.:85-164).

\section{Living Islam: Concepts of Authentic Lifestyle among young Turkish Muslims in the Diaspora by Hans-Ludwig Frese}

This most recent and dense study of 2002 applies qualitative methods of social science combined with the theoretical background of religious studies. Frese asks whether history of migration has an impact on forms of religious organisation and whether changes correspond to new readings and interpretations of religion. He focuses on communities and their policy of religion or religious education on the one hand and on adolescents on the other, taking into consideration the particular situation of migration of the third generation (Frese, 2002:11 ff., 21). Young Muslims engaged within the community are a minority within a minority. Committed Muslims do not consider their religious denomination as one cultural particularity among others as is the case for the majority of Turkish adolescents. Selfconceptions of the youngsters can be described as hybrid identities. The interviewed adolescents are searching for an authentic Islamic answer to reality in the German societal context. For them Islam is a means of integration and an integral part of public discourse (ibid.:11, 306). Tradition as presented by the parents' generation is questioned, reinterpreted and altered, as is the case with religious authorities and organisations (ibid.:278287). The author concludes that processes of individualisation of religion are taking place. This leads to the introduction of new images of Islam. Since these adolescents insist on being Muslims in Germany processes of detaching from Turkish influence are taking place, thus opening spaces for contextualised Islam, i.e. Islam in Germany (ibid.:305).

It has to be emphasised that the abovementioned studies were done either interviewing only male Muslim adolescents, or without using the analytical tool of gender-analysis. This is most regrettable, since the already limited mosaic does not consider female Muslim adolescents, though they are in focus in the public discourse. ${ }^{8}$ One reason is probably the fact that numerous committed Muslim women are veiled, therefore they are visible and recognisable as religious persons. The issue of the veil and the one-dimensional interpretation of this piece of cloth by the dominant (Christian) majority reflects the latter's uncertainties and the difficulties, if not incompetence, in handling Islam as a societal fact. However, it is beyond the scope of this paper to introduce results of studies tackling the situation of Muslim

The most striking example is the ongoing debate on the veil and the question whether a committed Muslim teacher should be allowed to wear a headscarf or whether this should be forbidden by law. See also footnote 4 above. 
women in Germany and their religious self-conceptions, although it would be appropriate (e.g. Karaka oğlu-Aydın, 2000a; 2000b; Mihciyazgan, 1994; Swietlik, 2000). ${ }^{9}$ It should be clear now that the few existing studies are heterogeneous to such an extent that it is difficult to compare them.

\section{Selected Results Obtained by Comparing the Outlined Studies}

Muslim adolescents no longer perceive the migration of their families as a temporary position as was the case with the first and second generation, i.e. their grandparents or parents. On the contrary they stress that there are ready to enter into German social life. This position implies a critical perspective regarding their parents' attitudes toward the German majority of society and toward traditional values that apparently should be preserved in the diaspora. ${ }^{10}$ The changes within the context of migration have an impact on religion and individual approaches to religion. This is also true for the context of globalisation and individualisation within the German society. Committed adolescent Muslims are looking for an independent kind of religious knowledge, which often implies individualised knowledge. They make numerous efforts to acquire religious knowledge with autodidactic methods, a process that can be described as self-enlightenment with tendencies to focus more on scriptural Islam. This implies that the parents' religious traditions that are based more on so called popular Islam and oral tradition, are questioned and sometimes even corrected. The adolescents' criticism is extended to religious authorities, particularly hocas, i.e. religious heads of the community who come from Turkey where they were theologically trained. The criticism focuses on the fact that these men are neither familiar with the social and political context in Germany, nor with the particular needs of the second and third generation of Muslims in Germany.

Young Muslims in Germany insist on being different and simultaneously part of the society. The meaning of integration has changed: It is equal to the integration of cultivated difference and denies egalitarianism. Islamic lifestyle in multicultural and multi-religious Germany opens up new space for action. Religion is perceived as a space giving adolescents the opportunity to develop their position within their own community and the broader society. This strengthens their self-conception and the feeling of belonging. One important result shown by all the studies is the fact that the dominant public discourse which portrays an image of Islam being the obstacle to integration, does not correspond to the Muslim adolescents' reality. On the contrary, living as a committed Muslim in an almost secular sociocultural context is an opportunity for them to participate in socio-political discourses. The future will reveal how this might be realised.

Finally one has to stress an obvious turning point concerning migration that departs from the image of the dominant discourse regarding migrants: There is a growing separation of Turkish culture, more precisely the influence of Turkey, and Islam (Frese, 2002:298-302). In the long term this implies changes concerning the ideological hold Turkey has. For the German majority this implies a necessity to revise features generally as-

9 These studies on women are based on a small number of interviews and can be described as examining details. However, they bring out different tendencies in comparison to those with male interviewees. Female Muslims are looking for other forms of religious expression and religiosity than male Muslims. This is linked to the gender-specific context, perceptions and ascriptions within the German society.

10 This phenomenon is also well worked out by Rommelspacher (2002) with a particular focus on young girls and women concerning the issue of the veil/headscarf. 
cribed to the Muslim population. It implies also that Islam will become a normal part of current debates on religion as a way to give meaning.

\section{Conclusion: Challenges for Religious Education}

It is obvious that further research must be undertaken in order to develop concepts for religious education facing Germany's multicultural and multi-religious reality. A gender-perspective promises to deliver interesting results that will complete the already existing studies.

Religious education seems to offer space for religious plurality and inter-religious dialogue. This is particularly true for religious education with the support or the background of intercultural education, not to mention religious education in multi-religious and multicultural societies. This implies working with concepts of education which encourage competences that are required for dealing with societal changes and diversity. It also implies opening up spaces where difference is perceived as enriching and is therefore accepted, and where people learn to handle diversity in a creative way. It is needless to mention that such concepts will permeate all fields of education. For me one of the major challenges in developing new concepts for religious education consists in the following: First, general societal uncertainties in the field of religion, be it Christianity, Islam or other forms of spirituality as well as atheistic positions, have to be taken up and taken seriously. Second, the particular majority-minority situation needs to be reconsidered. This means addressing questions like: Who holds the power of definition, i.e. which perspective is the dominant one? Who dominates the discourses? Which perspective dominates existing concepts? Third, and perhaps the most difficult, in multicultural societies is that confrontation with the other and with different cultural standards along with all it implies, has to be stated as regular, as the norm, for everybody. However, in societies like the German one the minority is confronted with an additional problem, namely that the positions of the majority are presented as unquestionable. In contrast, the position of the minority is often one that suffers from a lack of understanding, demands for justification and similar obstacles. This, of course, has to be addressed. As long as the relation between majority and minority remains an unequal powerrelationship, concepts of multi-religious and inter-religious education will be difficult to establish. Changes must be initiated on a variety of societal and political levels; however, religious education can at least contribute to growing awareness with regard to the abovementioned challenges. A new form of religious education that acknowledges the changed social reality may in some cases even assist in changing perspectives, if not in shifting paradigms, among students.

\section{BIBLIOGRAPHY}

Alacaçioğlu, H 2000. Deutsche Heimat Islam. Münster: Waxmann.

Attia, I/Marburger, H (Hrsg.) 2000. Alltag und Lebenswelten von Migrantenjugendlichen. Frankfurt/M.: IKO-Verlag für interkulturelle Kommunikation.

Bundesministerium des Inneren, 2000. Antwort der Bundesregierung auf die große Anfrage der CDU-CSU-Bundestagsfraktion "Islam in Deutschland". Bundestagsdrucksache. $14 / 4530$.

Frese, H-L 2002. Den Islam ausleben. Konzepte authentischer Lebensführung junger türkischer Muslime in der Diaspora. Bielefeld: Transcript.

Heitmeyer, W (Hrsg.) 2003. Deutsche Zustände. Folge 2. Frankfurt am Main: Suhrkamp. 
Heitmeyer, Wilhelm/Müller, Joachim/Schröder, Helmut (Hrsg.) 1997. Verlockender Fundamentalismus. Türkische Jugendliche in Deutschland. Frankfurt am Main: Suhrkamp.

Islam Archiv Bremen, 2000. Bremen.

Karaka oğlu-Aydın, Y 2000a. Das Grundgesetz, die Pädagogik und orthodoxe Muslime. Kontroverse Positionen in der aktuellen Debatte um die Grenzen der Toleranz. Zeitschrift für Türkeistudien. 13(1):27-55.

-- 2000b. Studentinnen türkischer Herkunft an deutschen Universitäten unter besonderer Berücksichtigung der Studierenden pädagogischer Fächer. Alltag und Lebenswelten von Migrantenjugendlichen. Hrsg. Attia, I/Marburger, H Frankfurt/M.: IKOVerlag für interkulturelle Kommunikation. 101-126.

Lutz, H 1999. Von Grenzen, Pässen und Rechten. Europäische Szenarien. L'Homme. Zeitschrift für feministische Geschichtswissenschaft. Schwerpunkt "Staatsbürgerschaft" 1, 1999: 63-78.

Mette, N/Rickers, F 2001. Lexikon der Religionspädagogik. 2 Bde. Neukirchen-Vluyn: Neukirchener Verlag.

Mihciyazgan, U 1994. Die religiöse Praxis muslimischer Migranten. Ergebnisse einer empirischen Untersuchung in Hamburg. Dialog zwischen den Kulturen. Erziehungshistorische und religionspädagogische Gesichtspunkte interkultureller Bildung. Hrsg. Lohmann, I/Weiße, W. Münster: Waxmann. 195-206.

Rohe, M 2001a. Der Islam - Alltagskonflikte und Lösungen. Freiburg: Herder.

-- 2001b. Islam und deutsche Rechtsordnung. Islam in Deutschland. Hrsg. Landeszentrale für politische Bildung Baden-Württemberg. 51(4):233-240.

Rommelspacher, B 2002. Anerkennung und Ausgrenzung. Deutschland als multikulturelle Gesellschaft. Frankfurt am Main/New York: Campus Verlag.

Sandt, Fred Ole. 1996. Religiosität von Jugendlichen in der multikulturellen Gesellschaft. Münster: Waxmann.

Spuler-Stegemann, U 2001. Muslime in Deutschland. Organisationen und Gruppierungen. Islam in Deutschland. Hrsg. Landeszentrale für politische Bildung. 51(4):221-225.

Statistisches Bundesamt. 2000. Wiesbaden.

Swietlik, G 2000. “Als ob man zwei Köpfe in einem hätte “- Religiöse Sozialisation zwischen Islam und Christentum. Alltag und Lebenswelten von Migrantenjugendlichen. Hrsg. Attia, I/Marburger, H Frankfurt/M.: IKO-Verlag für interkulturelle Kommunikation. 139155.

Tietze, N 2001. Islamische Identitäten. Formen muslimischer Religiosität junger Männer in Deutschland und Frankreich. Hamburg: Hamburger Edition. 